\title{
An Evaluation of the Romanian Fruits and Vegetables Producers Access to Different Types of Common Agricultural Policy Instruments. Is there Any Real Consistency with the Policy Objectives?
}

\author{
Nicu MARCU ${ }^{1}$, Georgeta-Mădălina MEGHIȘAN²*, Ionel Mugurel JITEA ${ }^{3}$ \\ 'Romanian Academy, 125Victoriei Street,010071,Bucharest, Romania; marcu.nicu@yahoo.com \\ ${ }^{2}$ University of Craiova, Faculty of Economics and Business Administration, 13 Al. I. Cuza Street, Craiova, \\ Romania;madalina_meghisan@yahoo.com ( ${ }^{*}$ correspondingauthor) \\ ${ }^{3}$ University of Agricultural Sciences and Veterinary Medicine, 3-5 Manastur St., 400372, Cluj-Napoca, Romania;mjitea@usamvcluj.ro
}

\begin{abstract}
Fruits and vegetables sectors are considered to be strategic in the European Union due to their contribution to a better human health. Among others positive effects, their intake increase reduce mortality and obesity, assuring in the same time harmonised development for young children. The present study thus focused to reveal the consistency of the measure implemented in the Common Agricultural Policy to support fruits and vegetables production in Romania in liaison with the policy objectives. The country is one of the main ten important European producers of horticultural products in terms of production volumes and acreage. Results showed that over the last seven years (2007-2014), the sectorial production drawbacks have not been ameliorated very much. Both sectors are dominated by small-size farms that can produce only seasonally and mainly for short-market chains. In the same time, the greenhouses area shrink to levels that made the country extremely dependent to imports especially for tomatoes. The analysis of the pillar one payments schemes revealed that the fruits and vegetables producers could have access to only one payment that was half from European averages. Moreover, almost half of the producers had low sizes that left them outside the eligible criteria. The measures designed for the second pillar also penalized producers through the selection criteria. These results showed that for Romania there was not a real consistency between the actual policy measures and the objectives assumed by policy makers. The future measures (2014-2020) seem to correct these negative findings being better tailored to the situation of the local fruits and vegetables producers.
\end{abstract}

Keywords: access to payments, fruit, human health, small-size farms, vegetables

\section{Introduction}

The Common Agricultural Policy has been shaping the European agricultural sector for more than 60 years now. Its history is closely linked to the evolution of the European Union (EU). The first years (1955-1992), presumed important financial transfers from consumers to producers through minimum guaranteed prices targeted to bust the agricultural productivity (Ackrill, 2000). This early strategic options produced between others also some well-recognised negative side effects like ground - water pollution due to increased use of pesticides and fertilisers (Rabbinge and Van Latesteijn, 1992), biodiversity loses (Benton et al., 2003), high budgetary pressures, marginal land abandonment and rural depopulation (MacDonald et al., 2000). Since then, the policy has being several times reformed (1992 McSherry reform; Agenda 2000; 2003 Luxembourg Agreement and 2013 Ciolos reform) in order to better orientate the producers towards market, to reduce its high budgetary costs, to recognise the multifunctional role of agriculture, to respond to external pressures (World Trade Organisation) or to allow the EU extension to the East (Bureau et al., 2012; Donald et al., 2002; Renting et al., 2009).

Therefore, in the present context, agriculture and rural areas do not produce only food but also important societal advantages like environmental goods, farmland as cultural heritage, biodiversity and environmental quality (Pretty et al., 2001). They were recognised to be important incentives also by the buyers (Hall et al., 2004). Over the last years, much emphasis has been also devoted to develop a policy targeted to support human health (Lock, 2004). Previous studies demonstrated that the cardiovascular disease burden attributable to CAP to be substantial due to the incentives for a dietary saturated with fats (Lloyd-Williams et al., 2008). Moreover, as a result of fruits and vegetables market withdrawal supports, the prices are usually high having as a consequence the limitation of their consumption (Veerman et al., 2005). A special programme was designed to increase fruit and vegetable consumptions by giving 
244

them for free to the children school population. Results showed that school schemes can be effective in increasing both intake and knowledge about fruit and vegetable consumption (De Sa and Lock, 2008).

Only few studies had previously analysed the CAP effects on the EU or a Member State fruits and vegetables sectors. Rickard and Sumner (2011) highlighted that the major policy changes for processed fruits and vegetables from 2001 and 2008 and the EU subsidies reform increased EU tomato production by 3.8\% for the regime that began in 2008 and $9.1 \%$ for the regime that began in 2001. Moreover, after the Uruguay Round Agreement on Agriculture (URAA) EU has signed trade preference treaties particularly with Southern Mediterranean countries that are important suppliers of fruits and vegetables to the EU. The subsidies devoted to these sectors proved not to be able to boost the EU exports of eligible products (Cioffi and dell'Aquila, 2004). Fewer studies were even reported for the New Member States (NMS) that are located in the Eastern part or Europe. Pomerleau et al. (2006) showed that the number of lives potentially saved annually if fruit and vegetable intake increased to $600 \mathrm{~g}$ per person per day would reach 423000 persons in NMS.

Romania is one of the most important horticultural producers from the European Union, with rank 6 for total cultivated surfaces (after France, Spain, Poland, Italy and Germany) and accounting for about $5 \%$ in total $\mathrm{EU}$ production volume (EVD, 2009). For this NMS only a limited number of studies analysed the CAP effects at producer-side level. There are studies that considered the importance of Agro Environment Measures (AES) for High Nature Value permanent grassland areas (Jitea and Arion, 2015). In our knowledge, there is no study that questions the access to the CAP for fruits and vegetables producers. Thus the paper has several objectives: to address the evolution of the Romanian fruit and vegetables sector in the last 25 years; to investigate the access to CAP pillar's payments for the local fruits and vegetables producers; to evaluate the investment possibilities that exist in the rural development programme (pillar 2); to see if the policy objectives related to human health were further implemented in the practice.

\section{Materials and methods}

The outcomes of agricultural policies can be evaluated by econometric estimations, computable general equilibrium models (CGE), through micro simulation models (MSM) or case-study assessments (Janssen and van Ittersum, 2007). The methodology largely depends on the research aims and data disposal. The models usually presume to simulate the environment of the offer-side operators and then to introduce information about the new policy incentives such as to reveal their potential outcomes at macro (CGE) or farm level (MSM). The methodology used in this research is mainly based on the bibliographical and case-study assessment (Yin, 2012). This approach was less time and resource consuming allowing in the same time good assessment of the access to different types of CAP measures for fruits and vegetables producers.

These two sectors were analysed based on the secondary official statistic data (Romanian National Institute of Statistics Tempo Online data base; EUROSTAT; FAOSTAT etc.) on a 20-25 year time frame. The structural characteristics investigated over time were acreage and production in volume units, farm number and acreage distribution in different size classes but also fruit and vegetables food balance. Descriptive analyses such as frequencies, percentages, means and indexes were performed to understand the changes produced over time at the farm structure level (Healey, 2012). The food balance was analysed based on FAOSTAT data and methodology (FAO, 2001). Two indicators were calculated in order to judge country's dependency to imports (1) and the self-sufficiency in fruits and vegetables products (2).

$$
I D R=\frac{\text { Imports }}{\text { Production+Imports- Exports }} * 100
$$

and

$$
S S R=\frac{\text { Production }}{\text { Production+Imports-Exports }} * 100
$$

Where: IDR - import dependency ratio; imports, production and exports expressed in volume; SSR - self-sufficiency ratio;

The access to different types of subsidies (first pillar) and rural development funds (second pillar) was evaluated by analysing the eligible criteria from the CAP legal framework (Regulation (EU) 1782/2003; 73/2009; 1305/2013; 1307/2013). Also different versions of fund guides were further investigated for Measure 112 'The Installation of the young farmers' (six different calls between 2007 and 2013; one after 2014) and 121 'Modernisation of agricultural holdings' (ten different calls between 2007 and 2013; one after 2014) to qualitatively appreciate the link between policy measures and stated policy objectives.

\section{Results}

Romanian fruits and vegetables sector - evolution, current situation

The offer-side of the Romanian vegetables sector knew several important structural changes between 1990 and 2013. The total acreage decreased at the beginning of the period due to huge structural reforms achieved in the early 90s that destructurated the former state owned farms (1990 to 1995). After that, the area allocated to vegetables increased with almost $20 \%$ due to the open field production. Unfortunately, the greenhouse acreage diminished to less than 25\% in 2013 as compared with 1990 (Fig. 1). In the same time, the area covered by orchards also decreased with more than $35 \%$ (Fig. 2).

More than $80 \%$ of fruit and vegetables producers are concentrated in size classes less than 5 hectares. Only around $40 \%$ of acreage is exploited in farms bigger than 5 hectares for fruit production (Fig. 3). The structural situation is better for the vegetables growers where $50 \%$ of land is located in farm classes bigger than 5 hectares (Fig. 4).

Over the last 20 years (1989-2011), the domestic consumption of fruits and vegetables has been increasing in Romania, especially due to imports. The reduction of greenhouse acreage made the country dependent to foreign products during the cold months. Thus, the import dependency ratio reached $34 \%$ for tomatoes and around $12 \%$ for fruits (Fig. 5). Also, the self-sufficiency ratio is very low for tomatoes and fruits (Fig. 6); these are the products that should receive special attention from the policy makers in the near future having in mind the stated CAP objectives. 


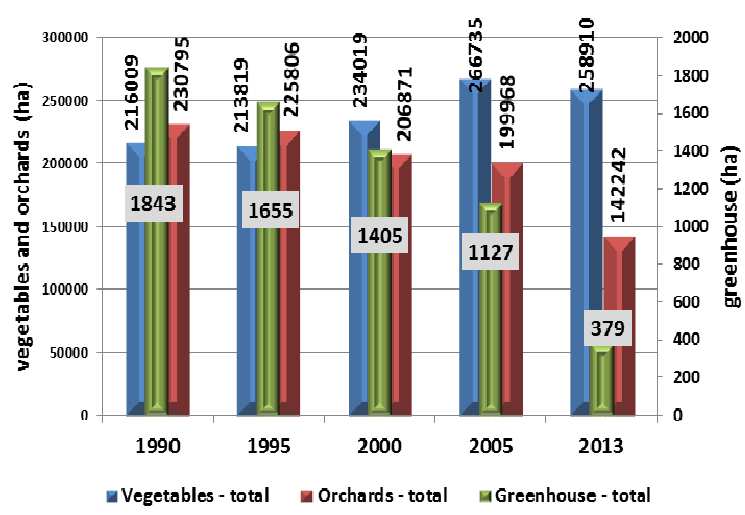

Fig. 1. The evolution of total vegetables and fruit areas Source: INSSE - Tempo on line (last accessed March 2015)

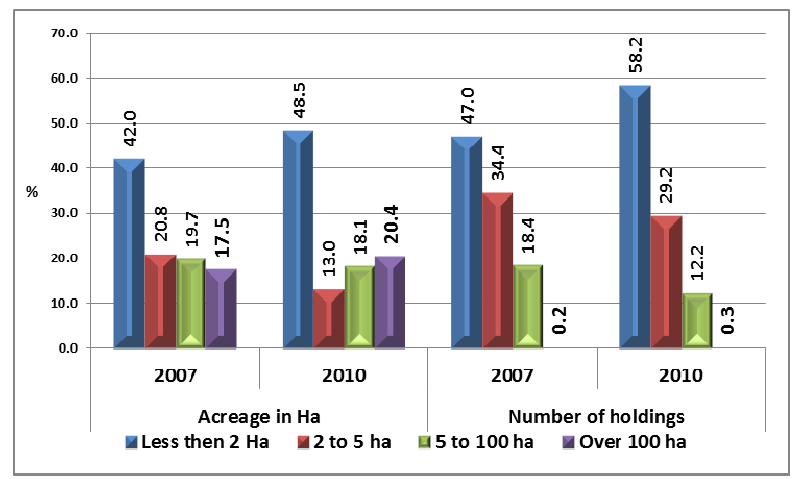

Fig. 3. The distribution of fruit acreage and number of holdings in different farm sizes

Source: EUROSTAT (last accessed March 2015)

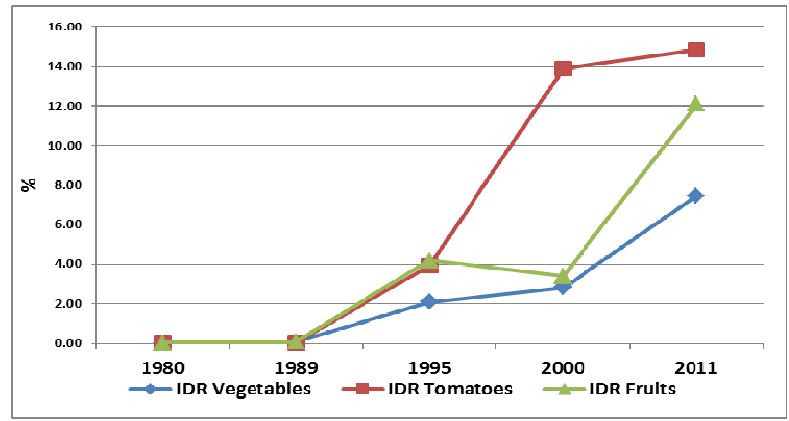

Fig. 5. Romanian import dependency for fruits and vegetables Source: FAOSTAT (last accessed March 2015)

CAP pillar 1: access to different type of subsidies for fruits and vegetablesproducers

Since 2007, farmers have been annually receiving CAP payments (Regulation (EU) 1290/2005). The single area payment is a direct subsidy linked to the utilized agricultural area (120 Euros/hectare in 2014 for farms bigger than 1 hectare and plots bigger than 0.3 hectares; 0.1 for orchards). It can be supplemented with additional complementary payments for the permanent pastures (50 Euros/hectare/year), for the livestock (8 Euros/breeding ewes/year or 100 Euros/breeding cow/year) or for specific crop production (rye, sugar beet etc) (Table 1). Also

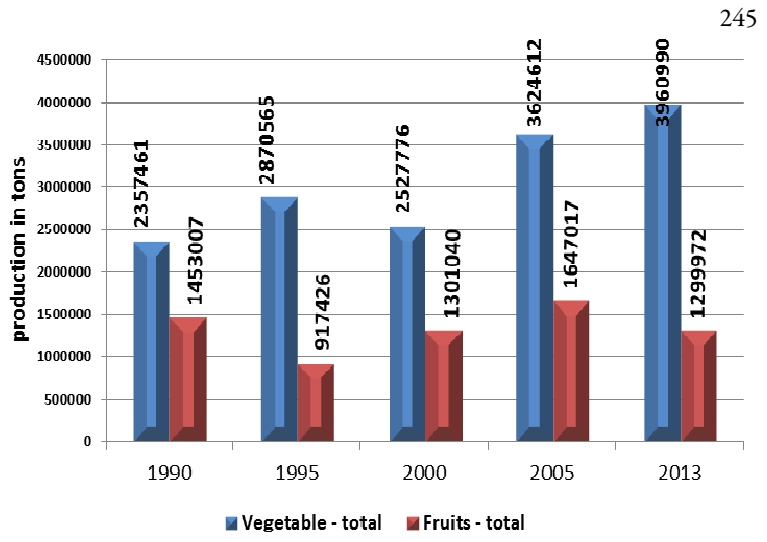

Fig. 2. The evolution of total vegetables and fruit production Source: INSSE - Tempo on line (last accessed March 2015)

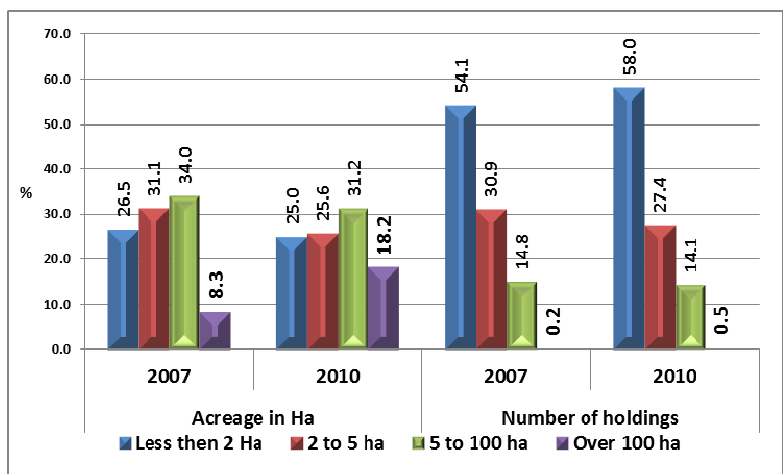

Fig. 4. The distribution of vegetable acreage and number of holdings in different farm sizes

Source: EUROSTAT (last accessed March 2015)

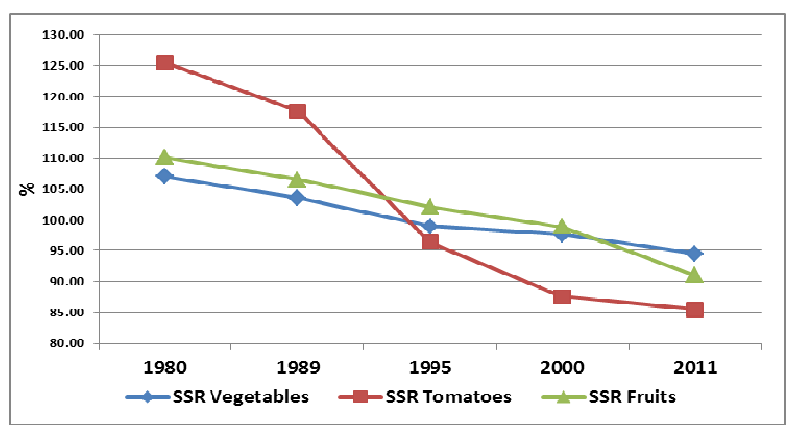

Fig. 6. Romanian sufficiency ratio for fruits and vegetables Source: FAOSTAT (last accessed March 2015)

five AES were implemented: high value natural grasslands (124 Euros/hectare/year); traditional agriculture practices (58 Euros/hectare/year); meadows, important for bird conservation (209 or $101 \mathrm{Euros} /$ hectare/year); green crop production (rape seed, peas, mustard etc.) and ecological production.

The conventional fruit and vegetables production sector could access mainly one type of payments from the first CAP pillar: the single area payment. The certificated ecological farmers could also access two special designed agro-environmental measures, but their effectiveness was rather limited due to high conversion costs. 
Table 1. The comparative level of different payments from the Romanian CAP pillar 1

\begin{tabular}{|c|c|c|c|c|c|c|c|c|c|}
\hline Payment type & U.M. & 2007 & 2008 & 2009 & 2010 & 2011 & 2012 & 2013 & 2014 \\
\hline Single Area Payment & Euros/ha & 50.55 & 60.75 & 71.12 & 80.36 & 90 & 100 & 110 & 120 \\
\hline National Complementary Payments (crop sector) & Euros/ha & 47.00 & 46.71 & 44,64 & 50.64 & 50.64 & 50.64 & 50.64 & 50.64 \\
\hline National Complementary Payments (cow) & Euros/Head & 100 & 100 & 120 & 97.39 & 90 & 90 & 90 & 90 \\
\hline National Complementary Payments (sheep and goat) & Euros/Head & 9.50 & 9.50 & 9.50 & 9.50 & 10 & 10 & 10 & 10 \\
\hline $\mathrm{HNV}$ permanent grasslands & Euros/ha & 124 & 124 & 124 & 124 & 124 & 124 & 124 & 124 \\
\hline Mountain Area & Euros/ha & 50 & 50 & 50 & 50 & 50 & 50 & 50 & 50 \\
\hline Ecological Vegetables & Euros/ha & -- & 335 & 335 & 335 & 335 & 335 & 335 & 335 \\
\hline Ecological Orchards & Euros/ha & -- & 393 & 393 & 393 & 393 & 393 & 393 & 393 \\
\hline
\end{tabular}

Table 2. The comparative analysis of the financial allocation in different axes and measures and the access to funds for Romanian fruit and vegetables produces (million Euros)

\begin{tabular}{|c|c|c|c|c|c|c|c|c|c|c|c|}
\hline \multicolumn{3}{|c|}{ Axis 1} & \multicolumn{3}{|c|}{ Axis 2} & \multicolumn{3}{|c|}{ Axis 3} & \multicolumn{3}{|c|}{ Axis 4} \\
\hline Measure & $\begin{array}{c}\text { Public } \\
\text { expenses }\end{array}$ & $\begin{array}{c}\text { Access to } \\
\text { funds }\end{array}$ & Measure & $\begin{array}{c}\text { Public } \\
\text { expenses }\end{array}$ & $\begin{array}{l}\text { Access to } \\
\text { funds }\end{array}$ & Measure & $\begin{array}{c}\text { Public } \\
\text { expenses }\end{array}$ & $\begin{array}{l}\text { Access to } \\
\text { funds }\end{array}$ & Measure & $\begin{array}{c}\text { Public } \\
\text { expenses }\end{array}$ & \\
\hline 111 & 78.9 & No & 211 & 673.5 & No & 312 & 456.2 & No & 4.1 & 296.1 & No \\
\hline 112 & 302.2 & Yes & 212 & 471.9 & No & 313 & 304.1 & No & 4.21 & 7.6 & No \\
\hline 114 & 0 & & 214 & $1,270.7$ & No & 322 & $1,610.9$ & No & 4.31 & 63.1 & No \\
\hline 121 & $1,028.5$ & Yes & 215 & 372.9 & No & & & & & & \\
\hline 122 & 2.3 & No & & & & & & & & & \\
\hline 123 & 963.2 & Yes & & & & & & & & & \\
\hline 125 & 523.6 & No & 221 & 33 & $\mathrm{No}$ & & & & & & \\
\hline 141 & 357.6 & Yes & 221 & 3.3 & No & & & & & & \\
\hline 142 & 22.4 & No & & & & & & & & & \\
\hline 143 & 12.3 & No & & & & & & & & & \\
\hline
\end{tabular}

Table 3. Comparative description of different funds access criteria for measures 112/6.1 from the Romanian Rural Development Programme

\begin{tabular}{|c|c|}
\hline Description & $112 / 6.1$ \\
\hline Eligible criteria & $\begin{array}{l}\text { 2007-2013: Age: } 18-40 \text { years; Size: 6-40 ESU; ; at least } 4 \text { ESU increase after } 3 \text { years of the project; Juridical: low demands; } \\
\text { 2014-2020: Age: } 18-40 \text { years; Size: } 12.000-50.000 \mathrm{SO}^{*} \text {; Juridical: medium. }\end{array}$ \\
\hline Conversion criteria & $\begin{array}{l}\text { 2007-2013: } 1 \text { ha Fresh vegetables, melons, strawberries - open field }=3.94 \mathrm{ESU} \text {; } \\
1 \text { ha Fresh vegetables, melons, strawberries - market orientated gardens }=5.69 \mathrm{ESU} ; 1 \text { ha Fresh vegetables, melons and strawberries - in } \\
\text { greenhouses and solariums }=35.954 \mathrm{ESU} ; 1 \text { ha Fruit trees (apple orchards, pear, plum, peach, apricot, cherry) }=1.169 \mathrm{ESU} ; 1 \text { ha Fruit trees } \\
\text { (walnut orchards, hazelnut, almond, chestnut) }=0.946 \mathrm{ESU} ; 1 \text { ha blueberry, fig, raspberry }=2.94 \mathrm{ESU} \text {; } \\
\text { 2014-2020: } 1 \text { ha Fresh vegetables, melons, strawberries - open field = 7,113.49 SO; } 1 \text { ha Fresh vegetables, melons, strawberries - market } \\
\text { orientated gardens }=7,914.85 \mathrm{SO} ; 1 \text { ha Fresh vegetables, melons and strawberries - in greenhouses and solariums = 37,209.23 SO; } 1 \text { ha Fruit } \\
\text { trees (apple orchards, pear, plum, peach, apricot, cherry) }=2,703.58 \mathrm{SO} ; 1 \text { ha Fruit trees (walnut orchards, hazelnut, almond, chestnut) } \\
\text { 1,556.94 SO; } 1 \text { ha blueberry, fig, raspberry }=3,430.92 \mathrm{SO} \text {. }\end{array}$ \\
\hline Funds limit & $\begin{array}{l}\text { 2008-2011: } \min 10000-\max 25000 \text { euro; } 2011-2013: \min 12000-\max 40000 \text { Euros; No cofinance } \\
\text { 2014-2020: } 40000 \text { Euros, the farm is between } 12,000 \text { and } 29,999 \mathrm{SO} \text {; } \\
50000 \text { Euros, the farm is between } 30,000 \text { and } 50,000 \mathrm{SO} \text {; No cofinance. }\end{array}$ \\
\hline Funds allocation & $\begin{array}{l}\text { 2008-2013: Two tranches ( } 60 \% \text { when signing the contract; } 40 \% \text { after } 30 \text { months); at least } 30 \% \text { of funds invested to meet EU standards; } \\
\text { 2014-2020: Two tranches ( } 75 \% \text { when signing the contract; } 25 \% \text { after } 36 \text { months). }\end{array}$ \\
\hline
\end{tabular}

\section{CAP pillar 2: the access to different types of investment funds}

Between 2007 and 2013 the Romanian National Development Plan was divided in four axis: 1. 'Competitiveness'; 2. 'Environment and land management'; 3. 'Economic diversification and quality of life' and 4. 'Leader' (Table 2). The main important measures that allowed access for investments funds for the vegetables and fruits growers were 112 'Installation of young farmers', 121 'Modernisation of agricultural holdings'

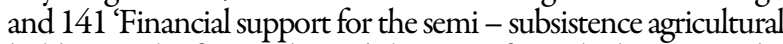
holdings'. The figures showed that even from the beginning the fruits and vegetables sector was eligible for only one third of the entire budget (123 'Marketing of agricultural products' was available for big food processors).

Between 2007 and 2013 the access to funds for the Romanian young persons who wanted to install in fruits and vegetables sector has started from 1.52 ha of fresh vegetable in open field, 0.17 ha greenhouses or 5.13 ha of fruit trees growing (Table 3). Starting with 2014, the financial allocation increased to a maximum threshold of 50,000 Euros per farm (measure 6.1 from the Romanian National Development Program 20142020). To be eligible a farmer should have at least 1.68 ha fresh vegetables in open field or 0.32 ha greenhouses. In the same time the eligible criteria became more difficult, especially due to the concern of being considered an active farmer registered as a legal person.

The selection criteria from the period 2008-2013 did not give any comparative advantages for vegetables and fruits sector, but for the period 2014-2020 these types of farming will be advantaged due to improved selection criteria (Table 4). 
Table 4. Comparative selections criteria for the measures 112 and 6.1

\begin{tabular}{|c|c|c|c|}
\hline \multicolumn{2}{|c|}{$112: 2008-2013$} & \multicolumn{2}{|l|}{$6.1: 2014-2020$} \\
\hline Criteria & Points & Criteria & Points \\
\hline \multirow{4}{*}{ Semi-subsistence farm } & \multirow{4}{*}{20} & Production sector & \\
\hline & & -vegetables & 30 \\
\hline & & -seeds and seedlings & 25 \\
\hline & & -fruit growing & 20 \\
\hline \multirow{4}{*}{ Farm in a disadvantage area } & \multirow{4}{*}{15} & Consolidation of holdings & \\
\hline & & -three farms & 15 \\
\hline & & -two farms & 10 \\
\hline & & -one farm & 5 \\
\hline \multirow{4}{*}{ The applicant owns the farm } & \multirow{4}{*}{30} & Education level & \\
\hline & & -bachelor & 25 \\
\hline & & - after high school & 20 \\
\hline & & - qualification course & 10 \\
\hline \multirow{2}{*}{ Part of an associative structure } & \multirow{2}{*}{20} & Agricultural potential & 25 \\
\hline & & -medium agricultural potential & $\begin{array}{l}25 \\
20\end{array}$ \\
\hline Agro-measure accessed by the farm & 15 & Local varieties & 5 \\
\hline
\end{tabular}

Table 5. Comparative description of different funds access criteria for measures 121/6.3 from the Romanian Rural Development Programme

\section{Description}

(1)

Eligible criteria

2007-2013: high legislative incertitude (ten different guides with different criteria); Size: farms bigger than 2 ESU;

2014-2020: Size: farms between 8.000 and 11.999 SO; Education: at least lower secondary education; Juridical: to be registered as a legal entity; to sell minimum $20 \%$ from the production until the second payment tranche.

2007-2009: maximum eligible limit 2,000,000 Euros; the non-refundable funds 50\% from the eligible budget; this limit can be increased with $5 \%$ for the young farmers (less than 40 years old) or with $10 \%$ for the investments from the mountain area; Co finance needed;

Funds limit 2009-2013: maximum eligible limit 2,000,000 EuroS; the non-refundable funds $40 \%$ from the eligible budget; this limit can be increase with $10 \%$ for the young farmers (less than 40 years old) or with $10 \%$ for the investments from the mountain area; Co finance needed; 2014-2020: 15.000 Euros for 3 years ( 5 years for fruits growing sector); No co finance needed.

Funds allocation 2008-2013: reimbursed after the project is implemented;

2014-2020: Two tranches (75\% when signing the contract; $25 \%$ after finishing the business plan - no later than 3 or 5 years).

ESU= Economical Size Unit $(1 \mathrm{ESU}=1200$ EuroS/year);

$\mathrm{SO}=$ Standard Output

Source: Own analysis based on different Romanian Agency for payments guides.

Table 6. Comparative selections criteria for the measures 121 and 6.3

\begin{tabular}{|c|c|c|c|c|}
\hline \multicolumn{2}{|l|}{ 112: October 2008} & \multirow{2}{*}{$\frac{\text { 112: } \text { March } 2012}{\text { Points }}$} & \multicolumn{2}{|l|}{$6.3: 2014-2020$} \\
\hline Criteria & Points & & Criteria & Points \\
\hline \multirow{4}{*}{$\begin{array}{l}\text { Farms that adapt to the new EU cross- } \\
\text { compliance rules }\end{array}$} & \multirow{4}{*}{10} & \multirow{4}{*}{0} & Production sector (crop) & \\
\hline & & & -vegetables & 15 \\
\hline & & & -seeds and seedlings & 12 \\
\hline & & & -fruit growing & 10 \\
\hline \multirow{3}{*}{$\begin{array}{l}\text { Priority sector, irrigation systems and } \\
\text { renewable energy }\end{array}$} & \multirow{3}{*}{35} & \multirow{3}{*}{50} & Production sector (animal breeding) & 15 \\
\hline & & & $\begin{array}{l}\text {-cow } \\
\text {-beekeeping }\end{array}$ & 12 \\
\hline & & & -sheep and goats & 10 \\
\hline \multirow{3}{*}{ Semi-subsistence farm } & \multirow{3}{*}{5} & \multirow{3}{*}{5} & Education level: & 20 \\
\hline & & & - after high school & 15 \\
\hline & & & - qualification course (Level I) & 10 \\
\hline Part of an associative structure & 10 & 10 & \multirow[t]{2}{*}{ - initiation course / training / specialization } & \multirow{2}{*}{5} \\
\hline No other EU funds accessed & 5 & 10 & & \\
\hline Certified ecological production & 5 & 7 & $\begin{array}{l}\text { Agricultural potential } \\
\text {-high agricultural potential }\end{array}$ & 30 \\
\hline Investments that have food processing facilities & 10 & 5 & -medium agricultural potential & 25 \\
\hline $\begin{array}{l}\text { Farms own by young farmers (less than } 40 \\
\text { years) }\end{array}$ & 15 & 8 & Farms that are between $(8,000-11,999 \mathrm{SO})$ & 30 \\
\hline Disadvantage agricultural area & 5 & 5 & Local varieties & 5 \\
\hline
\end{tabular}

\section{$112 / 6.3$}


248

The measure 121 has been dominated by high legislative incertitude during the time span. The funds guides were changed ten times during that period. The access to funds was even harder for the two sectors because the co-finance demands were high (Table 5). Practically only big-size farms (bigger that $100 \mathrm{ha}$ ) could access this type of funds. For the future financial period the reforms are better targeted for the local small undercapitalised producers. Thus, they will get $75 \%$ of the funds in advance without having to finance the entire project and then to be reimbursed.

In addition, the selection criteria for this measure did not give any comparative advantages for vegetables and fruits sector (20082013). On the other hand, the 20142020 budgetary allocations seems to bring comparative advantages in project selection criteria for fruits and vegetables producers (Table 6). Next to these two measures there is a special design one for fruits sector (4.1.a). It will financially support investments in the modernization of fruit farms, including tree plantations and reconversion.

\section{Discussions}

The effects of CAP implementation in Romania were also studied by Hubbard et al. (2014) at Romanian agriculture level. These Governmental expenses did not obviously contribute to farm consolidation, but rather to a gradual disappearance of semisubsistence farms. The present study also shows that CAP framework did not achieve a better way of organising the fruits and vegetables sectors. Swain (2013) also showed that the financial supports went especially to the big farms (12.05 per cent from the first CAP pillar in Romania was devoted to only 0.03 per cent of farms) which proved that the Western policy model was not adapted for the Eastern agricultural structures. Moreover, it was appreciated that the CAP fails to effectively integrate Central and Eastern Europe (CEE) into the European Union (Gorton et al., 2009).

The paper shows that there was an important policy pressure on small-size farms that operates in the Romanian fruits and vegetables sectors induced by subsidy/funds access criteria. They were excluded from payments even from the policy design. In the same time they have to compete with heavily intensive production systems from Western Europe that respond to the on-going important increase demand for food (Tilman et al., 2002). This is in contradiction with all political view-points and researches that showed the benefits of the traditional low intensive farming (high biodiversity; low content of pesticides and fertilisers etc.) (Bignal and McCracken, 1996; Fischer $e$ t al., 2012). Moreover, even if Eastern Europe was recognized to be one of the main keepers of traditional European farming practices being reached in valuable local plants varieties (Mikulcak et al., 2013) the average subsidies per hectare (pillar 1) arrive to only half of the European Figures (European Commission, 2011). Therefore, the near future calls for increased attention to properly deal with negative findings. It was found that especially the fruit and vegetables sectors were penalised through policy regulations. These findings are against all policy objectives that demand measures to support human health through increased uses of fruits and vegetables.

\section{Conclusions}

The paper demonstrates that Romanian fruits and vegetables sector is still dominated by small-size producers that have difficulties in accessing all types of CAP instruments. Between
2007 and 2013, the policy was orientated to support big-size farms and other agricultural sectors like crop production and animal breeding. Thus, the paper demonstrates that there was an important inconsistency between the policy objectives that called for increase used of fruits and vegetables and the measure implemented in Romania. These findings are in contradiction with all studies that point out the importance of local traditional farming. The future CAP measures (2014-2020) seem to correct these findings being better targeted to the real needs and situation of the local producers.

\section{Acknowledgements}

This paper was published under the frame of European Social Fund, Human Resources Development Operational Programme 2007-2013, projectno. POSDRU/159/1.5/S/132765.

\section{References}

Ackrill R (2000). Common Agricultural Policy. Sheffield Academic Press, England, 243 p.

Benton TG, Vickery JA, Wilson JD (2003). Farmland biodiversity: is habitat heterogeneity the key? Trends in Ecology and Evolution 18(4):182-188.

Bignal EM, McCracken D (1996). Low-Intensity Farming Systems in the Conservation of the Countryside. Journal of Applied Ecology 33(3):413-424.

Bureau JC, Tangermann S, Matthews A, Viaggi D, Crombez C, Knops L, Swinnen J (2013). The Common Agricultural Policy after 2012. Intereconomics 47(6):316-342.

Cioffi A, dell'Aquila C (2004). The effects of trade policies for fresh fruit and vegetables of the European Union. Food Policy 29(2):169-185.

De Sa J, Lock K (2008). Will European agricultural policy for school fruit and vegetables improve public health? A review of school fruit and vegetable programmes 18(6):558-568.

Donald PF, Pisano G, Rayment MD, Pain DJ (2002). The Common Agricultural Policy, EU enlargement and the conservation of Europe's farmland birds. Agriculture, Ecosystems and Environment 89(3):167-182.

European Commission (2011). Impact Assessment: Common Agricultural Policy towards 2020. Brussels, 85 p.

EVD International Business and Cooperation (2009). Market survey Romania - Fruits and Vegetables. The ministry of Economic Affairs, EVD:2-51.

Fischer J, Hartel T, Kuemmerle T (2012). Conservation policy in traditional farming landscapes. Conservation Letters 5(3):167-175.

Food and Agriculture Organisation of the United Nations (2001). Food balance sheets: a handbook. FAO, Rome:1-95.

Gorton M, Hubbard C, Hubbard L (2009). The Folly of European Union Policy Transfer: Why the Common Agricultural Policy (CAP) Does Not Fit Central and Eastern Europe. Regional Studies 43(10):1305-1317.

Hall C, McVittie A, Moran D (2004). What does the public want from agriculture and the countryside? A review of evidence and methods. Journal of Rural Studies 20(2):211-225. 
Healey JF (2012). Statistics a tool for social research (ninth edition). Cengage Learning, USA, $521 \mathrm{p}$.

Hubbard C, Luca L, Luca M, Alexandri C (2014). Romanian farm support: has European Union membership made a difference? Studies in Agricultural Economics 116:100-106.

Janssen S, van Ittersum MK (2007). Assessing farm innovations and responses to policies: A review of bio-economic models. Agricultural Systems 94(3):622-636.

Jitea IM, Arion FH (2015). The role of agri-environment schemes in farm economic sustainability from High Natural Value Transylvanian areas. Environmental Engineering and Management Journal 14(4):719-964.

Lloyd-Williams F, O'Flaherty M, Mwatsama M, Birt C, Ireland R, Capewell S (2008). Estimating the cardiovascular mortality burden attributable to the European Common Agricultural Policy on dietary saturated fats. Bull World Health Organ 86(7):535-542.

Lock K (2004). Why should public health be part of an integrated European agriculture and food policy? Eurohealth 10(1):1-3.

MacDonald D, Crabtree JR, Wiesinger G, Dax T, Stamou N, Fleury P, Gutierrez Lazpita J, Gibon A (2000). Agricultural abandonment in mountain areas of Europe: Environmental consequences and policy response. Journal of Environmental Management 59(1):47-69.

Mikulcak F, Newig J, Milcu A, Hartel T, Fischer J (2013). Integrating rural development and biodiversity conservation in Central Romania. Environmental Conservation 40(2):129-137.

Pomerleau J, Lock K, McKee M (2006). The burden of cardiovascular disease and cancer attributable to low fruit and vegetable intake in the European Union: differences between old and new Member States. Public Health Nutrition 9(05):575-583.

Pretty J, Brett C, Gee D, Hine R, Mason C, Morison J, Rayment M, Van Der Bijl G, Dobbs T (2001). Policy challenges and priorities for internalizing the externalities of modern Agriculture. Journal of Environmental Planning and Management 44(2):263-283.

Rabbinge R, Van Latesteijn HC (1992). Long-term options for land use in the European community. Agricultural Systems 40(1-3):195210.

Regulation (EU) 1290/2005 on the financing of the Common Agricultural Policy (2005). Official Journal of the European Communities L 209/1, 11.8.2005, Brussels, 55 p.

Regulation (EU) 1305/2013 of the European Parliament and of the Council on support for rural development by the European Agricultural Fund for Rural Development (EAFRD) (2013). Official Journal of the European Union L 347:487-548.
Regulation (EU) 1307/2013 of the European Parliament and of the Council establishing rules for direct payments to farmers under support schemes within the framework of the Common Agricultural Policy (2013). Official Journal of the European Union L347:608-670.

Regulation (EU) 1782/2003 of the European Parliament and of the Council establishing common rules for direct support schemes under the common agricultural policy and establishing certain support schemes for farmers (2003). Official Journal of the European Union 46(L 270):1-69.

Regulation (EU) 73/2009 of the European Parliament and of the Council establishing common rules for direct support schemes for farmers under the Common Agricultural Policy and establishing certain support schemes for farmers (2009). Official Journal of the European Union 52(L 30):16-99.

Renting H, Rossing WAH, Groot JCJ, Van der Ploeg JD, Laurent C, Perraud D, Stobbelaar DJ, Van Ittersum MK (2009). Journal of Environmental Management 90(2):112-123.

Rickard BJ, Sumner DA (2011). Was there policy "reform"? Evolution of EU domestic support for processed fruits and vegetables. Food Policy 36(3):438-449.

Romanian National Rural Development Plan (RNRDP). (2013). Romanian Government. Bucharest:429-430.

Romanian National Institute of Statistics (2015). TempoOnline data base (last accessed March 2015).

Swain N (2013). Agriculture 'East of the Elbe' and the Common Agricultural Policy. Sociologia Ruralis 53(3):369-389.

Tilman D, Cassman KG, Matson PA, Naylor R, Polasky S (2002). Agricultural sustainability and intensive production practices. Nature 418:671-677.

Veerman JL, Barendregt JJ, Mackenbach JP (2005). The European Common Agricultural Policy on fruits and vegetables: exploring potential health gain from reform. The European Journal of Public Health 16(1):31-35.

Yin RK (2012). Applications of case study research (3rd edition). Sage Publication LTD. United Kingdom p 217. 